\title{
Gambaran kadar C-reactive protein (CRP) serum pada perokok aktif usia $>40$ tahun
}

\author{
${ }^{1}$ Hendrika N. C. Dewi \\ ${ }^{2}$ Michaela E. Paruntu \\ ${ }^{2}$ Murniati Tiho
}

\author{
${ }^{1}$ Kandidat Skripsi Fakultas Kedokteran Universitas Sam Ratulangi Manado \\ ${ }^{2}$ Bagian Biokimia Fakultas Kedokteran Universitas Sam Ratulangi Manado \\ Email: hendrikadewi12052@gmail.com
}

\begin{abstract}
Cigarette are the most cause of death around the world. Smoking cigarrete is harmful to the organs because it contains many toxic chemical that can stimulate inflammatory process. Smoking cigarrete is a risk factors for heart disease and chronic pulmonary disease (COPD). C-reactive protein (CRP) are a non spesific inflammatory marker that can elevated in both local and systemic disease. Beside biomarker, CRP also use as prognostic marker for inflammation. The purpose of this study was to identify the level of serum CRP of smokers aged $>40$ years old. Twenty eight smokers were eligible to this criteria and participated in this study. Cross-sectional design with a descriptive method was employed in this study. Sampels were analysed in laboratory for serum CRP levels. The results showed that 23 subjects (82\%) had normal (negatif) serum CRP level and five subjects (18\%) had positive serum CRP level. It can be concluded that serum CRP level of $>40$ years old smokers in Kolombo village, west Bitung two were mostly in normal level.
\end{abstract}

Keywords: $c$-reactive protein (crp), active smoker, at age $>40$ years old

\begin{abstract}
Abstrak: Rokok menjadi salah satu penyebab kematian terbesar di dunia. Merokok membahayakan hampir semua organ tubuh karena mengandung berbagai bahan kimia berbahaya yang dapat merangsang proses peradangan dan merupakan faktor utama penyakit jantung dan penyakit paru obstruktif kronik (PPOK). C-Reactive Protein (CRP) merupakan petanda inflamasi non-spesifik yang meningkat pada penyakit lokal maupun sistemik. Selain biomarker CRP juga dijadikan sebagai penanda prognostik untuk inflamasi. Tujuan dari penelitian ini untuk mengetahui kadar CRP serum pada perokok berusia $>40$ tahun. Dua puluh delapan perokok memenuhi syarat untuk kriteria ini dan berpartisipasi dalam penelitian ini. Penelitian ini menggunakan desain cross-sectional dengan metode deskriptif. Kadar CRP serum sampel dianalisis di laboratorium. Hasil penelitian menunjukkan bahwa 23 subyek (82\%) memiliki kadar CRP serum normal (negatif) dan lima subjek (18\%) memiliki kadar CRP serum positif. Dapat disimpulkan bahwa kadar CRP serum perokok berusia $>40$ tahun di desa Kolombo, Bitung barat dua kebanyakan dalam kadar normal.
\end{abstract}

Kata kunci: c-reactive protein (crp), perokok aktif, usia $>40$ tahun.

Merokok sudah menjadi bagian dari gaya hidup di berbagai negara. Di Indonesia, rokok sudah menjadi bagian dari pergaulan, salah satu contoh yang bisa diamati yaitu kebiasaan menyuguhkan rokok dalam kegiatan atau acara yang berlangsung. Rokok yang dihisap mengandung berbagai macam bahan kimia berbahaya yang dapat merangsang proses inflamasi. ${ }^{1}$

Rokok dihasilkan dari tanaman nicotiana tabacum, nicotiana rustica, dan spesies lainnya atau sintetisnya yang asapnya mengandung nikotin dan tar, dengan atau tanpa bahan tambahan. ${ }^{2}$ 
Merokok membahayakan hampir semua organ tubuh dan merupakan faktor risiko utama terjadinya beberapa penyakit dengan komponen inflamasi, termasuk penyakit kardiovaskular dan penyakit paru obstruktif kronik (PPOK). ${ }^{1,3}$

Rokok juga telah menjadi salah satu penyebab kematian terbesar di dunia. Diperkirakan sekitar tiga juta orang di seluruh dunia meninggal setiap tahunnya akibat rokok. ${ }^{1}$ Sekitar $17,8 \%$ orang dewasa di Amerika (421 juta orang) merupakan perokok yang terdiri dari 20,5\% perokok pria dan $15,3 \%$ perokok wanita. ${ }^{4}$ Menurut Riset Kesehatan Dasar (RISKESDAS) tahun 2013, prevalensi perokok di Indonesia saat ini 29,3\%. Di Sulawesi Utara jumlah perokok setiap hari sebesar $24,6 \%$ dan yang jarang merokok sebesar $5,9 \%{ }^{5}$

C-reactive protein (CRP) ialah protein fase akut dengan struktur homopentamer dan memiliki tempat ikatan kalsium yang spesifik terhadap phosphocholin. ${ }^{6} \quad C$ reactive protein (CRP) bersama dengan serum amyloid $P$ component (SAP) merupakan anggota dari protein golongan pentraxins. Protein ini terdiri dari lima subunit yang identik (homopentamer) dengan berat subunit kurang lebih $23 \mathrm{kDa}$ yang berikatan secara non-kovalen dan tersusun secara simetris. ${ }^{7,8}$

CRP memiliki 206 residu asam amino. Dengan menggunakan mikroskop elektron, terlihat gambaran cincin (anular) molekul berbentuk donat. Struktur pentamer CRP memiliki sifat stabilitas molekul yang tinggi dan ketahanan terhadap serangan enzimatik. $^{9.10}$

CRP merupakan penanda inflamasi dan salah satu protein fase akut yang disintesis di hati untuk memantau secara non-spesifik penyakit lokal maupun sistemik. Kadar CRP meningkat setelah adanya trauma, infeksi bakteri, dan inflamasi. $^{11-13}$ Sebagai biomarker, CRP dianggap sebagai respon peradangan fase akut yang mudah dan murah untuk diukur dibandingkan dengan penanda inflamasi lainnya. CRP juga dijadikan sebagai penanda prognostik untuk inflamasi. ${ }^{12}$
Peningkatan kadar CRP berhubungan dengan penggunaan tembakau, peningkatan indeks massa tubuh, usia, hipertensi, resistensi insulin, diabetes, penyakit ginjal kronis, penurunan fungsi ventrikel kiri, aterosklerosis luas, infeksi aktif, dan depresi. ${ }^{14}$ Dalam penelitian Oshawa et al. ${ }^{15}$ yang dilakukan pada orang Japanese ethnicity (The Iwate-Kenpoku Cohort study) didapatkan peningkatan konsentrasi serum CRP namun tidak berhubungan dengan jumlah rokok yang dihisap per hari. Dalam Speedwell study yang di lakukan oleh Lowe et al. ${ }^{16}$ pada orang British (Inggris) dengan kebiasaan merokok dimana terdapat hubungan peningkatan CRP dengan jumlah rokok yang dihisap per hari. Di Sulawesi Utara, khususnya Kota Bitung penelitian tentang kadar CRP pada perokok belum pernah dilakukan, maka dari hasil uraian di atas penulis tertarik untuk mengetahui tentang gambaran CRP pada perokok aktif yang berusia $>40$ tahun.

\section{METODE PENELITIAN}

Jenis penelitian ini deskriptif dengan desain potong lintang. Penelitian dilaksanakan di desa Kolombo RT 04 lingkungan IV kota Bitung pada bulan Oktober 2015 hingga Januari 2016. Populasi penelitian ini yaitu responden yang berusia 40 tahun ke atas dan telah merokok selama lima tahun atau lebih. Teknik pengambilan sampel pada penelitian ini yaitu dengan total sampling, berusia 40 tahun ke atas dan perokok didapatkan dengan menggunakan kuesioner.

\section{HASIL PENELITIAN}

Pengambilan sampel dilakukan pada tanggal 12 Desember 2015 di Desa Kolombo RT 04 Lingkungan IV Kota Bitung. Pada penelitian ini sampel yang memenuhi kriteria sebanyak 28 sampel.

Berdasarkan jenis kelamin didapatkan sampel terbanyak berjenis kelamin laki-laki yang berjumlah 25 orang $(89,2 \%)$ dan yang berjenis kelamin perempuan berjumlah 3 orang (10,7\%). Berdasarkan usia, pada 
penelitian ini didapatkan usia $>40$ tahun dan terbanyak pada usia 40-49 tahun.

Berdasarkan hasil interpretasi kadar CRP, terdapat 23 orang (82\%) dengan hasil normal (negatif) dan lima orang (18\%) memiliki hasil positif.

\section{BAHASAN}

Berdasarkan hasil penelitian, dari 28 sampel didapatkan 23 sampel memiliki hasil kadar CRP normal (negatif). Hasil penelitian ini berbeda dengan beberapa penelitian yang menyatakan bahwa perokok aktif memiliki peningkatan pada kadar CRP. Seperti penelitian yang dilakukan oleh Lowe et al. ${ }^{16}$ pada tahun 2001 dalam Speedwell study yang di lakukan pada orang British (Inggris) dengan kebiasaan merokok dimana terdapat hubungan peningkatan CRP dengan jumlah rokok yang dihisap per hari. Penelitian Oshawa et al. ${ }^{15}$ pada tahun 2005 yang dilakukan pada orang Japanese ethnicity juga didapatkan peningkatan konsentrasi serum CRP namun tidak berhubungan dengan jumlah rokok yang dihisap per hari.

Hasil penelitian terhadap perokok berusia $>40$ tahun memiliki hasil kadar CRP normal. Hal ini bertentangan dengan teori yang mengatakan bahwa semakin bertambah usia konsentrasi CRP akan sedikit meningkat dan dengan bertambah usia akan terjadi penurunan fungsi dari organ tubuh. Usia perokok bukan merupakan faktor utama yang memengaruhi peningkatan kadar CRP melainkan aspek lain dari kebiasaan merokok. Menurut Harris. ${ }^{17}$ kebiasaan merokok seperti jenis rokok yang dihisap dan cara menghisap rokok (topografi merokok) terdapat kemungkinan selektif mempengaruhi hasil dari beberapa bahan kimia dalam asap rokok yang masuk ke tubuh.

Pada penelitian ini juga di dapatkan sebanyak lima orang memiliki hasil CRP positif yang sesuai dengan penelitian yang dilakukan oleh Gan et al. pada tahun 2005, Madsen et al. pada tahun 2007, Frohlich et al. pada tahun 2003, dan Wannamethee et al. pada tahun 2005 dimana menunjukkan adanya peningkatan kadar CRP pada perokok aktif usia $>40$ tahun. Penelitian $\mathrm{Gan}^{18}$ pada perokok aktif usia $\geq 40$ tahun memiliki peningkatan kadar CRP sebesar 63\%. Pada penelitian yang dilakukan Madsen ${ }^{19}$ pada pria berusia 67-77 tahun didapatkan hasil kadar CRP meningkat tinggi pada perokok, dibandingkan mantan perokok dan yang tidak merokok. Penelitian Frohlich ${ }^{20}$ berdasarkan pria dan wanita berumur 25-74 tahun menemukan pada pria yang merokok menunjukan nilai penanda fase akut positif konstan dan statistik signifikan lebih tinggi dibandingkan dengan wanita. Penelitian Wannamethee $^{21}$ juga menemukan pada pria perokok usia 60-79 tahun tanpa riwayat penyakit jantung menunjukkan peningkatan yang signifikan pada kadar CRP, sel darah putih dan fibrinogen.

\section{SIMPULAN}

Berdasarkan hasil penelitian dan bahasan dapat disimpulkan bahwa sebagian besar perokok aktif $\geq 40$ tahun memiliki hasil kadar CRP negatif (normal).

\section{DAFTAR PUSTAKA}

1. Suiraoka IP. Penyakit Degeneratif. Yogyakarta: Nuhamedika, 2012; p. 16-9.

2. Peraturan Pemerintah RI nomer 109. Pengamanan bahan yang mengandung zat adiktif berupa produk tembakau bagi kesehatan. 2012 [cited 2015 Oct 13]. Available from:

http://sipuu.setkab.go.id/PUUdoc/173 643/PP1092012.pdf

3. Tonstad S, Cowan JL. C-reactive protein as a predictor of disease in smokers and former smokers: a review. Int $\mathrm{J}$ Clin Pract. 2009;63(11):1634- 41.

4. Centers for Disease Control and Prevention. Smoking and Tobacco Use. April 2015 [cited 2015 Nov 04]. Available from:

http://www.cdc.gov/tobacco/data_stat istics/fact_sheets/adult_data/cig_smo king/

5. Riset Kesehatan Dasar (RISKESDAS). Pengetahuan, Sikap, dan Perilaku. Penggunaan Tembakau. 2013 [cited 
2015 Oct 12]. Available from: http://www.depkes.go.id/resources/do wnload/general/Hasil\%20Riskesdas\% 202013.pdf.

6. Volanakis JE. Human C-reactive protein : expression, structure, and function. Agustus 2001 [cited 2015 Feb 3]. Available from: http://www.ncbi.nlm.nih.gov/pubmed /11532280.

7. Salazar J, Martinez MS, Castillo MC, Nunez V, Anez R, Torres Y, d.k.k. C-reactive protein: an in-depth look into structure, function, and regulation.16 Desember 2014 [cited 2015 Nov 9]. Available from: http://dx.doi.org/10.1155/2014/65304 5.

8. Black S, Kushner I, Samols D. C-reactive protein. J Biol Chem. 2004; 279(47):48487-90 .

9. Pepys MB, Hirschfield GM. C-reactive protein: a critical update. J Clin Invest. 2003;111:1805-12.

10. Terry W, Du Clos. Pentraxins: Structure, function, and role in inflammation. 19 August 2013 [cited 2015 Oct 22]. Available from: http://dx.doi.org/10.1155/2013/37904 0 .

11.Sacher RA, McPherson RA. Prinsipprinsip mikrobiologi klinis. Tinjauan klinis hasil pemeriksaan laboratorium (11th ed). Jakarta; EGC, 2004; p. 389.

12.Chung SH, Makambi KH, Soldin OP. Tobacco smoke exposure, C-reactive protein and steroid hormones measured by Tandem Mass Spectrometry in healthy women. J Steroid Hormon Sci. 2014;15.(4):1-6.

13.Tymchak LL. Amino acids and proteins. In: Bishop LM, Fody Ep, Schoeff LE editors. Clinical Chemistry (6th ed). Philadelphia: Wolters Kluwer, 2010; p. 245.

14.Deron SJ. C-reactive protein: an inflammatory biomarker in clinical practice. J Lancaster General Hospital. 2007;2:63.

15.Oshawa M, Okayama A, Nakamura M, Onoda T, Kato K, Itai K, et al. CRP levels are elevated in smokers but unrelated to the number of cigarettes and are decreased by long-term smoking cessation in male smokers. Agustus 2005 [cited 2016 Feb 1]. Available

from:www.ncbi.nlm.nih.gov/pubmed/ 15917065.

16. Lowe GDO, Yarnell JWG, Rumley A, Bainton D, Sweetnam PM. Creactive protein, Fibrin D-Dimer, and incident ischemic heart disease in the Speedwell study: are inflammation and fibrin turnover linked in pathogenesis?. Arterioscler Thromb Vasc Biol. 2001;21:p.603-10.

17. Harris JE. Cigarette smoke components and disease: cigarette smoke is more than a triad of tar, nicotine, and carbon monoxide. National Cancer Institute. [cited 2016 Apr 21]. Available from: http://cancercontrol.cancer.gov/brp/tc rb/Monographs/7/m7_5.pdf.

18. Gan WQ, Man SF, Sin DD. The interactions between cigarette smoking and reduced lung function on systemic inflammation. Feb 2005 [cited 2016 Feb 1]. Available from: http://www.ncbi.nlm.nih.gov/pubmed /15705996.

19. Madsen C, Nafstad P, Eikvar L, Schwarze PE, Ronningen KS, Haaheim LL. Association between tobacco smoke exposure and levels of C-reactive protein in the Oslo II Study. Eur J Epidemiol. 2007;22:31117.

20. Frohlich M, Sund M, Lowel H, Imhof A, Hoffmeister A, Koenig W. Independent association of various smoking characteristics with markers of systemic inflammation in men. Eur Heart J. 2003;24:1365-75.

21. Wannamethee SG, Lowe GDO, Shaper AG, Rumley A, Lennon L, Whincup PH. Associations between cigarette smoking, pipe/cigar smoking, and smoking cessation, and haemostatic and inflammatory markers for cardiovascular disease. Eur Heart J. 2005;26:1765-73. 